PUPIL: International Journal of Teaching, Education and Learning

ISSN 2457-0648

Rasmitadila et al., 2021

Volume 5 Issue 3, pp. 129-143

Received: 15 th September 2021

Revised: 20 th December 2021, 03 ${ }^{\text {rd }}$ January 2022, 09th January 2022

Accepted: 10 th January 2022

Date of Publication: 20th January 2022

DOI- https://doi.org/10.20319/pijtel.2021.53.129143

This paper can be cited as: Rasmitadila, Humairaa, M. A., Rachmadtullah, M. E Putri, A. A. (2021). Inclusive Elementary School Expectations University Engagement: Inclusive Education Practices in Indonesia. PUPIL: International Journal of Teaching, Education and Learning, 5 (3), 129-143.

This work is licensed under the CreativeCommons Attribution-NonCommercial 4.0 International License. To view a copy of this license, visit http://creativecommons.org/licenses/by-nc/4.0/ or send a letter to Creative Commons, PO Box 1866, Mountain View, CA 94042, USA.

\title{
INCLUSIVE ELEMENTARY SCHOOL EXPECTATIONS UNIVERSITY ENGAGEMENT: INCLUSIVE EDUCATION PRACTICES IN INDONESIA
}

\author{
Rasmitadila \\ Department of Elementary School Teacher Education, Universitas Djuanda, Bogor, Indonesia \\ Rasmitadila@unida.ac.id \\ Megan Asri Humaira \\ Department of Elementary School Teacher Education, Universitas Djuanda, Bogor, Indonesia \\ Megan.asri@unida.ac.id \\ Reza Rachmadtullah \\ Department of Elementary School Teacher Education, Universitas PGRI Adi Buana Surabaya, \\ Surabaya, Indonesia \\ rezarachmadtullah@unipasby.ac.id \\ Ayu Anggraini Putri \\ Department of International Relations, Universitas Nasional, Jakarta, Indonesia \\ Ayuanggraini2000@gmail.com
}

\begin{abstract}
The involvement of universities in inclusive education in inclusive elementary schools is still not maximal, and the real impact can be felt for improving the quality of inclusive primary schools.
\end{abstract}


This study aims to explore the opinion of general teachers (GT) on the expectations of university involvement in inclusive education practices in Indonesia. Data were collected using semistructured interviews of forty GTs in two provinces in Indonesia. Data were analyzed using thematic analysis. The research resulted in three main themes: inclusive school mentoring, majors relevant to inclusive education in universities, and students' understanding in an inclusive classroom. Universities must meet the needs of elementary school graduates who will teach inclusive classrooms based on the problems faced by GTs so far, including academic and nonacademic aspects. The results of this research are significant for universities to design courses that are relevant and in line with the needs of inclusive elementary schools. For this reason, all decision-makers at the university must be able to make and establish rules following the analysis of the needs of inclusive education practices.

\section{Keywords}

Inclusive Elementary School, University, Inclusive Education, Inclusive Classroom, Academic

\section{Introduction}

Implementing inclusive education in inclusive elementary schools must involve all internal and external parties. The involvement of internal parties such as the principal, teachers, school staff, students, and parents is one unit that must support each other solidly. Meanwhile, external parties such as the community, universities, and relevant experts also play a significant role. Good cooperation between the two parties provides an excellent opportunity to solve all the problems in inclusive education, especially in Indonesia. In particular, universities have a significant role in producing graduates - in education - who are expected to implement inclusive education practices in inclusive elementary schools (Kozibroda et al., 2020). Universities that organize special teacher education study programs or elementary school teacher education courses that hold inclusive education courses are an effort to bridge the needs and fulfillment of problem-solving in inclusive elementary schools. The university is expected to meet the needs of prospective elementary school teachers with problems that occur in elementary schools (Baharuddin \& Dalle, 2019). The subjects' programs must be able to be concretely practiced by prospective elementary school teachers. When teaching, they can carry out instruction with the competencies that have been obtained at the university. 
But so far, the involvement of universities in inclusive education in inclusive elementary schools has not been maximized, and the real impact can be felt for improving the quality of inclusive elementary schools (Causton-Theoharis et al., 2011; Gross, 2015). The school has only resolved the problems that occur in inclusive schools. There is rarely any direct involvement of the university that can contribute as problem solvers. For example, inclusive teachers find it difficult to design instruction according to their class characteristics with a variety of students with different abilities. Problems in instruction cause the teacher not to have the right and effective way of designing instruction.

Meanwhile, regulations from the government require that all elementary schools accept students with special needs to study together in regular primary schools. This condition causes the accumulation of problems in inclusive practices faced by inclusive teachers. Another problem is that universities have not been able to identify problems in inclusive elementary schools, so there is a gap between the material presented in university classes and the reality in inclusive elementary schools (Jacobs-Bell, 2014). As a result, graduates who teach in inclusive schools have not solved the problems in inclusive classrooms.

For this reason, universities must identify and analyze problems that often occur in inclusive elementary schools so that they become lecture topics or materials that can contribute to problem-solving for elementary school teacher graduates. Furthermore, universities must make a good portion of teacher theory and practice relevant to the existing instruction conditions in elementary schools (Li, 2020). All problems in implementing inclusive education with the need for inclusive education course materials must become a solution in the real practice of inclusive education in inclusive elementary schools. Inclusive elementary schools give high hopes for the university's involvement to develop inclusive education through the latest research on inclusive education (Ainscow \& Sandill, 2010). The research is expected to solve problems and provide school members with implementing inclusive education. This study explores general teacher (GT) expectations regarding university involvement in inclusive education in Indonesia.

\section{Literature Review}

This study uses several theories related to inclusive education and inclusive schools. Inclusive schools are part of the implementation of inclusive education. Through inclusive schools, 
the advantages and disadvantages of inclusive education can be seen as an effort to provide the best service for all children, in achieving education without discrimination.

\subsection{Inclusive Education}

Inclusive education illustrates that every child with uniqueness, limitations, weaknesses, and even advantages has the same right to get a proper education, participate in classrooms, and a conducive environment in getting achievements tailored to each child's abilities. According to the United Nations Educational \& Scientific and Cultural Organization (UNESCO, 2008), that inclusive education is:

"Inclusive education is concerned with removing all barriers to learning and with the participation of all learners vulnerable to exclusion and marginalization. It is a strategic approach designed to facilitate learning success for all children. It addresses the common goals of decreasing and overcoming all exclusion from the human right to education, at least at the elementary level, and enhancing access, participation and learning success in quality basic education for all”.

Inclusive education is concerned with removing all barriers to learning and the participation of all students vulnerable to separation and marginalization. It is a strategic approach designed to facilitate successful learning for all children. It aims to reduce and address all exclusions from the human right to education, at least at the primary level, and increase access, participation, and success in quality primary education for all learning. According to Puri \& Abraham (2004), inclusive education is education based on human rights and democratic principles as part of the concern in developing an inclusive society to ensure that some students are not neglected. Another opinion was expressed by Porter \& Smith (2012) that inclusive education is a place where students including students with disabilities and other special needs are educated in regular classes with their peers in their school environment. In addition, according to Corbett (2002), Fevrier (2013) emphasizes inclusive education about the quality of education, which focuses on learning development practices that are responsive to various learning styles.

Meanwhile, Stubbs (2002); Hankebo (2018) argues that inclusive education is a strategy that promotes effective universal education because it creates schools that are responsive to the diverse needs of children and communities that ensure access and quality of education. According to Miller et al. (2017); Mitchell (2014) state that inclusive education is a multi-component or multi- 
strategy strategy that places curriculum adjustments, teaching methods, assessments and even accessibility for every student and educator in the classroom.

Inclusive education in Indonesia is regulated by the Regulation of the Minister of National Education of the Republic of Indonesia Number 70 of 2009 concerning Inclusive Education for Students Who Have Abnormalities and Have Potential Intelligence and Special Talents, Article 1 that inclusive education is a system of providing education which provides opportunities for all students who have disabilities and have the potential for intelligence and special talents to participate in education or learning in an educational environment together with students in general. Furthermore, article 2 states that the objectives of inclusive education are: (1) To provide the widest possible opportunity for all students who have physical, emotional, mental, and social disabilities or have the potential for intelligence and special talents to obtain quality education according to their needs and abilities; (2) Realizing the implementation of education that respects diversity, and is not discriminatory for all students as referred to in letter a.

Inclusive education provides education for all children, including those with disabilities and other special needs who are educated in regular classes and their peers to achieve their learning and social success by using certain strategies in its implementation. Therefore, inclusive education emphasizes meeting the needs of every child, without discrimination and differences in getting decent and fair educational services in an opportunity and learning together with other children to achieve the real educational goals.

\subsection{Inclusive School}

Since it was stated in The Salamanca Statement 1994, inclusive education must be implemented by establishing inclusive schools that provide services for all children, including children with special needs. The main challenge in inclusive schools in developing pedagogy centered on children's abilities, weaknesses, strengths, and "handicaps." The advantage of inclusive schools is providing quality education for every child. Still, they are an essential step in changing discriminatory or unfair attitudes in people's lives to create an inclusive society.

Inclusive schools develop a strong commitment to accepting and respecting various forms of diversity and are sensitive to cultural issues by setting high but realistic standards (Mitchell, 2014; Theoharis \& Causton, 2014). Schools included in the category of inclusive schools according to Rasmitadila \& Anna (2018); Rose \& Howley (2006) is a school with teachers who have good skills and a high commitment to meeting all the needs of students with their diversity. 
In addition, inclusive schools provide diversity and difference by viewing them as a place to produce humans who have empathy, compassion, and mutual respect for fellow human beings.

Inclusive schools emphasize learning for all students, with their obstacles, weaknesses, and strengths. All students have different learning styles and ways according to their abilities. The elements that underlie the development of inclusive schools according to the Center for Studies on Inclusive Education (CSIE) consist of: (1) Community-based schools, all community members accept the existence of inclusive, open, positive schools in diversity; (2) Inclusive schools can be accessed by everyone which is not limited to physical buildings but includes curriculum, school support systems and communication that all members of the community can follow; (3) Offering cooperation with other schools or collaborating in its development not to compete with other schools; (4) Placing equality, namely the democratization of all members who have the same responsibilities and rights to be able to develop the inclusiveness provided by the school jointly.

\section{Research Methods}

This research uses a case study approach to obtain and examine data on a particular phenomenon or event. The subject of a case study in an educational context can be people, students, or school staff members of the school community (Crowe et al., 2011). The data generated from case studies are used to explain and describe a case that is deep and detailed in life comprehensively real (Yin, 2012).

\subsection{Participants}

Participants in this study were forty inclusive elementary school general teachers (GT) from schools designated as inclusive and general elementary schools that accept special needs students (SNS). GTs come from forty inclusive elementary schools from West Java and DKI Jakarta, Indonesia, and have experience teaching inclusive classrooms. All participants have had experience teaching in inclusive classrooms, with teaching time at most from 1-5 years. In addition, the education level of the most widely used is the bachelor level. Meanwhile, the GT taught types of SNS to consist of ADHD, slow learner, deaf, autism, down syndrome, speech impaired, learning difficulties, dyslexia, and dyscalculia.

\subsection{Data Collection}

Data collection was carried out by semi-structured interviews with open-ended questions conducted between the researcher and GT as participants. The researcher created an interview 
guide validated by two experts in the inclusive field and developed questions provided by the participants. Interviews were conducted for about 1-2 hours for each participant. In one day, as many as four respondents were interviewed, so a total of 10 days to carry out the interview. Interviews were conducted online using the Zoom application and by recording the interview contents. Then, the researcher transcribed all the interview content according to the interview's contents (Verbatim). The interview material relates to the involvement of universities in the practice of inclusive education in inclusive elementary schools, including the barriers, roles, and problems faced by inclusive elementary schools during inclusive practice (See Appendix 1).

\subsection{Data Analysis}

Data analysis used thematic analysis techniques to explore the opinion of the GTs. The data generated from each participant in the form of responses were made in several stages. In the first stage, codes (keywords) representing participant statements are made not to overlap. The second stage is the categorization of the codes that have been made. With the researcher's large amount of data, coding and categorization easier used the Nvivo 12 application. Finally, all interview data were entered and given codes and categories. Researchers analyze each categorization to allow for the integration or unification of codes to be more effective. This inductive technique enables the identification of themes expressed by participants in response to research questions (Liu, 2011).

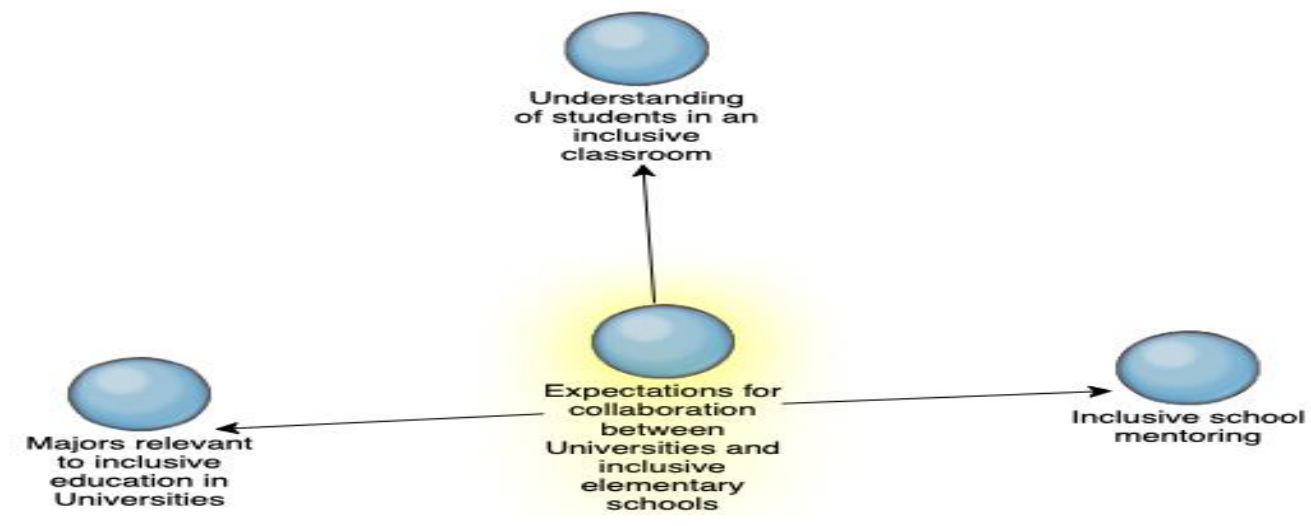

Figure 1: Results of data analysis inclusive elementary school expectations for university engagement

(Source: Rasmitadila, et.al (2021))

\section{Results and Discussion}


The results of the data analysis consisted of three main themes: inclusive school mentoring, majors relevant to inclusive education in universities, and understanding of students in an inclusive classroom.

\subsection{Inclusive School Mentoring}

Assistance for schools inclusive according to GT needs to be done by universities. Several important issues in this assistance include human resource development, improved instruction in inclusive classrooms, understanding of inclusive education. Human resource development in inclusive schools must involve all school members. Because the successful practice of inclusive education only can be successful if all school members support inclusive practice (Moriña, 2017). There are still many school members who have not fully supported inclusive practices in the field. Support from the community, parents, school authorities (school principals, teachers, school staff, students) has not fully implemented inclusive education (Alothman, 2014). Support for GTs and special assistant teachers (SAT) still needs improvement, such as developing various instructional strategies in an inclusive classroom. Besides, the involvement of school principals in determining policies and rules for inclusive schools must continuously improve to implement the quality of inclusive education practices maximally (Villa \& Thousand, 2016). All policies must be based on principles. The latest scientific developments must continuously upgrade to ensure inclusive practices in inclusive elementary schools properly. Meanwhile, the improvement of inclusive services, which are the duty of school staff, must constantly be improved. Such as the provision of facilities and infrastructure for inclusive schools suitable for an inclusive environment to support all students' academic and non-academic activities in inclusive elementary schools.

Mentoring programs for inclusive schools that universities can also carry out must increase instruction in inclusive classrooms (Sharma, 2018). The problem that often occurs and is most important in inclusive classrooms is the difficulty of GTs in designing effective instructional strategies that suit the needs and characteristics of all students. The university expected to develop various innovative and creative instructional strategies, which can implement in inclusive elementary schools. This statement, as stated by one of the GT:

"I hope the university can develop methods of innovative learning that can be practiced in inclusive classrooms so that instruction can take place following the characteristics of an inclusive classroom." 
In line with the development strategy of instruction in an inclusive classroom, the fundamental thing is very. The university can provide an understanding of inclusive education to all school members. The implementation of inclusive education will not run well if all school members do not understand the nature of inclusive education (Ntombela, 2011). The understanding of all school members about inclusive education has consequences for all procurement of inclusive education components. Components such as inclusive school facilities and infrastructure, instruction, costs to be paid by schools, and readiness of human resources are part of school assistance that can carry out between universities and inclusive elementary schools (Ediyanto et al., 2017; Rasmitadila et al., 2020).

University assistance to inclusive elementary schools is a form of moral responsibility in the success of inclusive education. Universities must produce graduates such as elementary school teacher education courses who must teach in inclusive elementary schools with diverse or inclusive students. Graduates must overcome all the problems in inclusive classrooms based on their learning experiences and practices while at university to be applied in inclusive elementary schools. University assistance to inclusive elementary schools must periodically carry out the university's positive involvement in solving problems in inclusive schools (Waitoller \& Kozleski, 2013).

\subsection{Majors Relevant to Inclusive Education}

The hope of GTs, which is very important to universities, is the department relevant to inclusive education in universities (Mag et al., 2017). GTs who has been teaching in inclusive classrooms are not relevant or have not received special education about inclusive education. As a result, it is difficult for GTs to practice inclusive education in inclusive classes. The problems faced by GTs, such as understanding the characteristics of SNSs are significant for GTs. So that can do learning problems and how to handle SNSs. Programs relevant to inclusive education, such as special education that are dominant with teachers' understanding of the characteristics of SNSs, creating individual learning programs (IEP), or identifying and assessing students are competencies that GTs must possess. This statement was put forward by one of the GT:

" What I hope is that the college can provide a special education department because there are very few universities that provide that department in Indonesia. Even though all teachers now have to teach inclusive classes. " 
The university must meet the limitations of every inclusive school, especially in improving the quality of inclusive teachers (Göransson \& Nilholm, 2014). In inclusive schools, not all GTs who teach in inclusive classrooms have a special education background that focuses on handling SNSs. The rules in the current government, general schools must accept SNSs regardless of their students' family background and characteristics. Consequently, all GTs must be able to serve and carry out instruction with the characteristics of all students. So, to overcome this condition, universities are expected to organize majors relevant to inclusive education. Such as a special education major, or at least there are inclusive courses in the teacher education major so that graduates or teacher candidates can practice inclusive education in inclusive classrooms.

\subsection{Understanding of Students in an Inclusive Classroom}

The problem that GTs often experiences in an inclusive class is the difficulty of GT in understanding the characteristics and types of SNSs. To understand the characteristics of all students, GT must identify and then assess (in collaboration with a psychologist) students who tend to have special needs. To carry out identification, not all teachers understand how to identify and or have the instruments provided by the school (Callejo \& Zapatera, 2017). The problem is getting a lot because not all of the GT backgrounds special education teachers or teachers who get courses inclusive education in college, so it is difficult for teachers to carry identification. This statement was made by one of the GT:

"I also need assistance in identifying students so that I know what kind of condition and type of students are."

Another impact is that when GT cannot identify all students, including SNSs, the services provided to SNSs are inappropriate and appropriate. If GT understands characteristics and needs, it will give some students with certain characteristics with handling and services. The differences and array of diverse SNSs in inclusive classrooms require special focus and handling in academic and non-academic aspects (Pather, 2015; Rasmitadila et al., 2021). In the academic aspect, the instruction method that must be designed by GT must be able to adapt to the characteristics of the SNSs. The material delivered by GT can be appropriately understood according to the ability SNSs. Likewise, with non-academic aspects, if SNSs experience emotional conditions that are difficult to control, the GTs will be easier to handle according to the characteristics of SNSs.

For this reason, the assistance carried out by universities to inclusive elementary schools, especially in providing an understanding of the characteristics and services of SNSs (Jordan et al., 
2009), must be carried out intensively and continuously, both in training activities for GTs in inclusive schools. Another activity is to make scheduled face-to-face visits so that the school always gets the correct and up-to-date information that can practice in inclusive classrooms.

\section{Conclusions}

The hope of inclusive elementary schools for university involvement in inclusive education in Indonesia can be done in a scheduled mentoring program and is carried out continuously. It is hoped that the engagement of universities in the practice of inclusive education can meet and solve the problems often faced by inclusive elementary schools, especially by teachers in inclusive classrooms. Universities must meet the needs of elementary school graduates who will teach inclusive classes based on the problems faced by GTs so far, including academic and non-academic aspects. The results of this study are significant for universities that provide elementary school teacher education and those that conduct courses inclusive education to design systems that are relevant and in line with the needs of teachers in inclusive primary schools. For this reason, all decision-makers at the university must be able to make and establish rules according to the analysis of the needs of inclusive education practices.

This study has limitations, especially related to the number of respondents involved, and in the conditions of the Covid-19 pandemic, it causes limited access and communication between researchers and respondents. Nevertheless, it is hoped that there will be involvement of the number of respondents who can represent the number of inclusive elementary schools that can provide maximum research results in the future.

\section{Acknowledgment}

The authors wish to thank the Ministry of Education, Culture, Research, and Technology of Indonesia as a part of the Research Grant PTUPT (2021). Thank the Directorate of Research and Service of Universitas Djuanda, which supported the research.

\section{REFERENCES}

Ainscow, M., \& Sandill, A. (2010). Developing inclusive education systems: The role of organisational cultures and leadership. International Journal of Inclusive Education, 14(4), 401-416. https://doi.org/10.1080/13603110802504903 
Alothman, A. (2014). Inclusive education for deaf students in Saudi Arabia: Perceptions of schools principals, teachers and parents (Doctoral dissertation, University of Lincoln).

Baharuddin, B., \& Dalle, J. (2019). Transforming learning spaces for elementary school children with special needs. Journal of Social Studies Education Research, 10(2), 344-365.

Callejo, M. L., \& Zapatera, A. (2017). Prospective primary teachers' noticing of students' understanding of pattern generalization. Journal of Mathematics Teacher Education, 20(4), 309-333. https://doi.org/10.1007/s10857-016-9343-1

Causton-Theoharis, J., Theoharis, G., Bull, T., Cosier, M., \& Dempf-Aldrich, K. (2011). Schools of promise: A school district-University partnership centered on inclusive school reform. Remedial and Special Education, 32(3), 192-205. https://doi.org/10.1177/0741932510366163

Corbett, J. (2002). Supporting inclusive education. Routledge.

Crowe, S., Cresswell, K., Robertson, A., Huby, G., Avery, A., \& Sheikh, A. (2011). The case study approach. BMC Medical Research Methodology, 11(1), 1-9. https://doi.org/10.1186/1471-2288-11-100

Ediyanto, E., Atika, I. N., Kawai, N., \& Prabowo, E. (2017). Inclusive education in Indonesia from the perspective of Widyaiswara in Centre for Development and empowerment of teachers and education personnel of kindergartens and special Education. IJDS: INDONESIAN JOURNAL OF DISABILITY STUDIES, 4(2), 104-116. https://doi.org/10.21776/ub.ijds.2017.004.02.3

Fevrier, M. M. (2013). The challenges of inclusive education in Haiti: Exploring the perspectives and experiences of teachers and school leaders (Doctoral dissertation, Union Institute and University).

Göransson, K., \& Nilholm, C. (2014). Conceptual diversities and empirical shortcomings - a critical analysis of research on inclusive education. European Journal of Special Needs Education, 29(3), 265-280. doi:10.1080/08856257.2014.933545

Gross, J. (2015). Strong School-Community Partnerships in Inclusive Schools Are" Part of the Fabric of the School... We Count on Them". School Community Journal, 25(2), 9-34. Hankebo, T. A. (2018). Inclusive education as an approach to reduce inequitable access to education: Exploring the practices of Jegnoch Metasebiya primary school in Harar town, 
Ethiopia. Journal of Teacher Education and Educators, 7(2), 123-138. https://doi.org/10.12973/iji.2018.11333a

Jacobs-Bell, T. (2014). Attitudes and inclusive practices: A dilemma for elementary school principals and special education administrators (Doctoral dissertation, Capella University).

Jordan, A., Schwartz, E., \& McGhie-Richmond, D. (2009). Preparing teachers for inclusive classrooms. Teaching and Teacher Education, 25(4), 535-542. https://doi.org/10.1016/j.tate.2009.02.010

Kozibroda, L. V., Kruhlyk, O. P., Zhuravlova, L. S., \& Chupakhina, S. V. (2020). Practice and Innovations of Inclusive Education at School. International Journal of Higher Education, 9(7), 176-186. https://doi.org/10.5430/ijhe.v9n7p176

Li, Z. (2020). Collaborative research approaches between universities and schools: The case of New Basic Education (NBE) in China. Educational Studies, 46(4), 385403. https://doi.org/10.1080/03055698.2019.1587593

Liu, L. (2011). An international graduate student's ESL learning experience beyond the classroom. TESL Canada Journal, 77-92. https://doi.org/10.18806/tesl.v29i1.1090

Mag, A. G., Sinfield, S., \& Burns, T. (2017). The benefits of inclusive education: New challenges for university teachers. 121, 12011. https://doi.org/10.1051/matecconf/201712112011

Miller, N. C., McKissick, B. R., Ivy, J. T., \& Moser, K. (2017). Supporting diverse young adolescents: Cooperative grouping in inclusive middle-level settings. The Clearing House: A Journal of Educational Strategies, Issues and Ideas, 90(3), 86-92. https://doi.org/10.1080/00098655.2017.1285661

Mitchell, D. (2014). What really works in special and inclusive education: Using evidence-based teaching strategies. Routledge.

Moriña, A. (2017). Inclusive education in higher education: Challenges and opportunities. European Journal of Special Needs Education, 32(1), 3-17. https://doi.org/10.1080/08856257.2016.1254964

Ntombela, S. (2011). The progress of inclusive education in South Africa: Teachers' experiences in a selected district, KwaZulu-Natal. Improving Schools, 14(1), 514. https://doi.org/10.1177/1365480210390082 
Pather, S. (2015). Pre-entry academic and non-academic factors influencing teacher education students'first-year experience and academic performance (Doctoral dissertation, Cape Peninsula University of Technology).

Porter, G. L., \& Smith, D. (2012). Exploring inclusive educational practices through professional inquiry. Springer Science \& Business Media.

Puri, M., \& Abraham, G. (2004). Handbook of inclusive education for educators, administrators and planners: Within walls, without boundaries. Sage.

Rasmitadila, R., \& Anna, R. S. T. (2018). Readiness of general elementary schools to become inclusive elementary Schools: A preliminary study in Indonesia. International Journal of Special Education, 33(2), 366-381.

Rasmitadila, R., Widyasari, W., Teguh, P., Megan Asri, H., Reza, R., Achmad, S., Muhammad, N., \& Rusi Rusmiati, A. (2020). Model of instructional strategy based on the brain's natural learning system in inclusive classrooms: Special teacher perceptions. International Journal of Advanced Science and Technology, 29(7), 3200-3211

Rasmitadila, R., Widyasari, W., Teguh, P., Reza, R., Achmad, S., \& Rusi Rusmiati, A. (2021). General Teachers' Experience of The Brain’s Natural Learning Systems-Based Instructional Approach in Inclusive Classroom. International Journal of Instruction, 14(3), 95-116. https://doi.org/10.29333/iji.2021.1436a

Regulation of the Minister of National Education of the Republic of Indonesia Number 70 of 2009 concerning Inclusive Education for Students Who Have Abnormalities and Have Potential Intelligence and/or Special Talents.

Rose, R., \& Howley, M. (2006). The practical guide to special educational needs in inclusive primary classrooms. Sage.

Sharma, U. (2018). Preparing to teach in inclusive classrooms. In Oxford Research Encyclopedia of Education. https://doi.org/10.1093/acrefore/9780190264093.013.113

Stubbs, S. (2002). Pendidikan Inklusif-Ketika hanya ada sedikit sumber. Oslo: Atlas Alliance.

Theoharis, G., \& Causton, J. (2014). Leading inclusive reform for students with disabilities: A school-and systemwide approach. Theory Into Practice, 53(2), 82-97. https://doi.org/10.1080/00405841.2014.885808

United Nations Educational, \& Scientific and Cultural Organization. (2005). Guidelines for Inclusion: Ensuring Access to Education for All. UNESCO. 
Villa, R., \& Thousand, J. (2016). The Inclusive Education Checklist: A Self-Assessment of Best Practices. National Professional Resources, Inc./Dude Publishing.

Waitoller, F. R., \& Kozleski, E. B. (2013). Understanding and Dismantling Barriers for Partnerships for Inclusive Education: A Cultural Historical Activity Theory Perspective. International Journal of Whole Schooling, 9(1), 23-42.

Yin, R. K. (2012). Case study methods. In H. Cooper, P. M. Camic, D. L. Long, A. T. Panter, D. Rindskopf, \& K. J. Sher (Eds.), APA handbook of research methods in psychology, Vol. 2. Research designs: Quantitative, qualitative, neuropsychological, and biological (pp. 141-155). American Psychological Association. https://doi.org/10.1037/13620-009

\section{Appendix 1}

\section{Questioner of interview}

1. Has there been a relationship between universities and inclusive elementary schools?

2. Why is there a need for a relationship between universities and inclusive elementary schools?

3. What are the benefits of cooperative relationships between universities and inclusive elementary schools?

4. What is the role of universities in helping inclusive elementary schools in solving problems so far?

5. What is an example of a cooperative relationship between a university and an inclusive elementary school? 